\title{
Successful Beit Alpha Cucumber Production in the Greenhouse Using Pine Bark as an Alternative Soilless Media
}

\author{
Nicole L. Shaw, ${ }^{1}$ \\ Daniel J. Cantliffe, ${ }^{2}$ \\ Julio Funes, ${ }^{3}$ and \\ Cecil Shine III ${ }^{4}$
}

Additional IndeX wORds. Cucumis sativus, hydroponic, protected agriculture, substrate

\begin{abstract}
Summary. Beit Alpha cucumber (Cucumis sativus) is an exciting new greenhouse crop for production in the southeastern U.S. and Florida. Beit Alpha cucumbers are short, seedless fruit with dark-green skin and an excellent sweet flavor. Beit Alpha-types are the leading cucumber types in the Middle Eastern market and have gained recent popularity in Europe. Beit Alpha cucumbers grown hydroponically under a protected structure have prolific fruit set, yielding more than 60 high-quality fruit per plant during one season. U.S. hydroponic vegetable production is generally associated with structure and irrigation investments which are costly as well as other inputs, such as the media, which must be replaced annually or with each crop. Beit Alpha cucumber 'Alexander' was grown in Spring 2001 and 2002 in a passive-ventilated high-roof greenhouse in Gainesville, Fla. Three media types, coarse-grade perlite, medium-grade perlite, and pine bark, were compared for efficiency of growing cucumbers (production and potential costs). During both seasons, fruit yield was the same
\end{abstract}

University of Florida, Institute of Food and Agricultural Sciences, Horticultural Sciences Department, P.O. Box 110690, Gainesville, FL 32611-0690. This research was supported by the Florida Agricultural Experiment Station, and approved for publication as journal series R-09597.

${ }^{1}$ Senior biological scientist; to whom reprint requests should be addressed; email nlshaw@ifas.ufl.edu.

${ }^{2}$ Chair/professor; email djc@ifas.ufl.edu.

${ }^{3}$ Undergraduate student.

${ }^{4}$ Agriculture assistant. 
among media treatments [average of $6 \mathrm{~kg}$ (13.2 lb) per plant]. Irrigation requirements were the same for each type of media; however, leachate volume was sometimes greater from pots with pine bark compared to either grade of perlite suggesting a reduced need for irrigation volume when using pine bark. Pine bark is five times less expensive than perlite and was a suitable replacement for perlite in a hydroponic Beit Alpha cucumber production system.

$\mathrm{I}$ n 2000, the Protected Agriculture Project (University of Florida, 2004) introduced the Beit Alpha cucumber to the Florida greenhouse vegetable industry (Shaw et al., 2000). Beit Alpha cucumber was developed in Israel for field production under intensive fertilization and irrigation practices. Beit Alpha-type cultivars grow well under extremes of environmental conditions, especially high temperatures of 35 to $40{ }^{\circ} \mathrm{C}$ (95.0 to $104.0^{\circ} \mathrm{F}$ ), but also continue to produce well at low temperatures of $15^{\circ} \mathrm{C}$ $\left(59.0^{\circ} \mathrm{F}\right)$ (Shaw et al., 2000). More recently, cultivars have been adapted for greenhouse production (Z. Karchi, personal communication) in which the plants are grown in containers using a trellis system (Shaw et al., 2000). Present Beit Alpha type cucumbers are hybrids that are gynoecious and parthenocarpic, thus they do not need to be pollinated by bumble bees ( Bombus spp.). The fruit is seedless and has a thin skin, similar to a greenhouse Dutch-type cucumber, but does not require plastic shrink-wrap to prevent dehydration after harvest. Fruit production is prolific for Beit Alpha cultivars; multiple fruits set at each node and on lateral branches. Plant production during the spring season can involve more than 30 harvests, yielding at least 65 fruit per plant (Shaw et al., 2000). As consumers become more familiar with the delicate sweet flavor of Beit Alpha cucumbers, their popularity will grow and their market-share might eventually dominate over other greenhouse or field cucumbers.

Information on the production of Beit Alpha cucumber is limited because it is a relatively new crop. Shaw et al. (2000) identified cultivars and techniques suitable for Beit Alpha cucumber production in a passive-ventilated-greenhouse using perlite as a growing media. Media comparisons for soilless melon (Cucumis melo group Reticulatus) (Guler et al., 1995) and tomato (Lycopersicon esculentum) (Jensen, 2001) productions have found no difference in fruit yield or quality between perlite and rockwool. It is unknown if other inexpensive media, such as pine bark, would be more suitable for soilless cultivation of Beit Alpha cucumber.

Several factors must be considered when selecting a media for soilless hydroponic vegetable production. A media must drain freely, especially as it ages, be easily aerated; have good water holding capacity; be nontoxic; and free of weeds, pests, diseases, and chemicals (Cantliffe et al., 2003). Furthermore, the media must be inexpensive (Cantliffe et al., 2001). The most common media for greenhouse vegetable production in Florida are perlite, rockwool, and sand/soil mixes (Tyson et al., 2001). However, some growers use pine bark, coconut coir and/or sphagnum peat mixes because of their satisfactory aeration and water holding capacity (Cantliffe et al., 2003).
Air porosity, moisture holding capacity, $\mathrm{pH}$, electrical conductivity, and nutrient availability should be considered when comparing the physical characteristics of soilless media types. Cantliffe et al. (2003) reported air porosity ranges from $12 \%$ for a sphagnum peat mix to $47 \%$ for pine bark and a moisture holding capacity of $17 \%$ for pine bark and up to $50 \%$ for a sphagnum peat mix. Furthermore, pH ranged 4 to 7 and electrical conductivity from 0.04 to $0.6 \mathrm{mS} \cdot \mathrm{cm}^{-1}$ (27 to $400 \mathrm{ppm}$ ) for coarse-grade perlite, medium-grade perlite, pine bark and sphagnum peat mixes (Table 1). Rockwool has an air porosity of $18 \%$, a moisture holding capacity of $80 \%$ and $\mathrm{pH} 7$. Coconut coir might vary with manufacturer; however, quality coir should have an air porosity of $16 \%$, a moisture holding capacity of $33 \%$ and pH 5 (Prasad, 1997).

Rockwool is used as a media in more than $60 \%$ of the vegetable greenhouses in the Netherlands but it is costly and difficult to dispose because it is not biodegradable. For example, 1 ha (2.47 acres) of greenhouse tomato production requires $72 \mathrm{~m}^{3}\left(2578 \mathrm{ft}^{3}\right)$ of rockwool at a cost of about $\$ 8000$, not including the cost of disposal (Benoit and Ceustermans, 1995). Perlite, which is less expensive than rockwool [ $\$ 45$ versus $\$ 98$ per $\mathrm{m}^{3}$ ( $\$ 1.27$ versus $\$ 2.78{\left.\text { per } \mathrm{ft}^{3}\right)}^{3}$ ], has been used around the world for production of vegetables, fruits, and cut flowers (Grillas et al., 2001). Coconut coir is in great demand by the ornamental industries in The Netherlands and Canada (Kaveri Agri-Care, 2004; Brown and Murphy, 2003), and more recently, the product has been marketed as a substitute for rockwool in the greenhouse vegetable industry. Coconut coir is suitable for

Table 1. Physical properties of media used in greenhouse vegetable culture.

\begin{tabular}{lcccc}
\hline Physical & \multicolumn{4}{c}{ Media type } \\
\cline { 2 - 5 } property $^{\mathrm{z}}$ & Coarse perlite & Medium perlite & Pine bark & Sphagnum peat mix $^{\mathbf{y}}$ \\
\hline Bulk density & & & & \\
$\quad$ Dry $\left(\mathrm{g} \cdot \mathrm{cm}^{-3}\right)$ & 0.17 & 0.12 & 0.22 & 0.11 \\
$\quad$ Wet $\left(\mathrm{g} \cdot \mathrm{cm}^{-3}\right.$ ) & 0.34 & 0.58 & 0.39 & 0.61 \\
Moisture capacity (\% vol.) & 17.2 & 45.9 & 16.9 & 50.0 \\
Gravimetric content (\% dry wt) & 102.3 & 387.6 & 75.3 & 643.5 \\
Total porosity (\%) & 57.8 & 62.9 & 63.6 & 61.9 \\
Air porosity (\%) & 40.6 & 17.0 & 46.7 & 11.9 \\
pH & 6.9 & 7.0 & 5.2 & 5.8 \\
EC $\left(\mu S \cdot \mathrm{cm}^{-1}\right)^{\mathrm{w}}$ & 0.06 & 0.04 & 0.06 & 0.62 \\
\hline
\end{tabular}

${ }^{2}$ Media depth $=17 \mathrm{~cm}$ (6.7 inches).

y 3 sphagnum peat: 1 coarse perlite:1vermiculite by volume (Cantliffe et al., 2003)

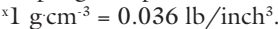

${ }^{\mathrm{w}} 1.0 \mu \mathrm{S} \cdot \mathrm{cm}^{-1}=0.67 \mathrm{ppm}$ total dissolved salts. 
disposal in landfill in the U.S. because it is $100 \%$ organic and biodegradable (Millenniumsoils Coir, St. Catherines, Ont., Canada).

The bark from pine is a by-product of sawmills and pulp mills where it is removed mechanically from the wood, stockpiled (Ingram et al., 1993), and sold at $\$ 8.50 / \mathrm{m}^{3}\left(\$ 0.24 / \mathrm{ft}^{3}\right)$ (Elixson Wood Products, Starke, Fla.). Thus, it is a relatively inexpensive media compared to perlite $\left(\$ 45 / \mathrm{m}^{3}\right)$, rockwool $\left(\$ 98 / \mathrm{m}^{3}\right)$, or coconut coir $\left[\$ 95 / \mathrm{m}^{3}\right.$ $\left.\left(\$ 2.69 / \mathrm{ft}^{3}\right)\right]$. Pine bark has been used for container-grown ornamental plants since the 1960s either alone or as a component of a mix (Ingram et al., 1993). Pine bark, like coconut coir, is organic and biodegradable allowing for easy disposal. Many growers cannot afford or do not have space to store large quantities of media; therefore, availability of product is important. Perlite, like pine bark, is locally available in Florida. Rockwool is imported from Denmark and coconut coir is imported from Sri Lanka, the Philippines, Indonesia, Mexico, and parts of the Caribbean and South America, for example, making them more costly to purchase due to transportation costs. Furthermore, small greenhouse growers may have to purchase much more than their need to get a reasonable bulk discount, leading to initial high costs and storage problems.

Perlite and rockwool are sterile and do not require fumigation as with sand/soil mixes. Coconut coir is sterilized before entry into the U.S. and is free of weeds and pathogens (Millenniumsoils Coir). Pine bark which has been naturally-composted (aged) for more than 15 years is organic and highly stable (Moutere River Co., 2004); thus, potential toxins are removed and nitrogen-consuming organisms have been neutralized. Pine bark and perlite can be easily wetted, however, rockwool and coconut coir require the use of wetting agents. To facilitate use, some rockwool and coconut coir products have been treated or washed, thus do not require wetting agents.

In 2005 , methyl bromide will no longer be available for use by vegetable growers in developed countries such as the U.S. Growers are currently looking for alternative yet economical production practices. One solution would be for growers to produce vegetables in containers using a soilless substrate such as perlite, coconut coir, or rock- wool. However, initial investments into greenhouse structures and containerized production systems might deter some growers from choosing such an option. Cost saving advantages such as using plastic greenhouses instead of glass, may entice field growers to invest in a protected agriculture system. Some growers might be able to lower their yearly cost of production by using a less expensive substrate. The objective of this research was to compare the effects of pine bark media and two grades of perlite on fruit yield, quality, and water use of Beit Alpha cucumber.

\section{Materials and methods}

On 20 Jan. 2001 and 14 Jan. 2002 , seeds of Beit Alpha cucumber 'Alexander' (Hazera Genetics, Brurim. D.N. Shikmim, Israel) were sown into styrofoam trays ( 128 cell count; Speedling, Bushnell, Fla.) using a media of 3 sphagnum peat : 2 vermiculite (by volume). In 2001, transplants were grown in an evaporative-cooled pad and fan glasshouse and in 2002; transplants were grown in Conviron E15 chambers (Controlled Environments Inc., Asheville, N.C.). In both years, temperatures were maintained at 28 ${ }^{\circ} \mathrm{C}\left(82.4^{\circ} \mathrm{F}\right)$ day $/ 22{ }^{\circ} \mathrm{C}\left(71.6^{\circ} \mathrm{F}\right)$ night with a 12 -h photoperiod (150 $\left.\mu \mathrm{mol} \cdot \mathrm{m}^{-2} \cdot \mathrm{s}^{-1}\right)$. Transplants were fertilized three times weekly with a 100 $\mathrm{mg} \cdot \mathrm{L}^{-1}(\mathrm{ppm})$ of $20 \mathrm{~N}-8.7 \mathrm{P}-16.6 \mathrm{~K}$ fertilizer solution with micronutrients (Peters 20-20-20 Professional All Purpose Plant Food; Spectrum Group, St. Louis, Mo.).

Cucumbers were grown in a passive-ventilated high-roof greenhouse (Top Ltd., Rosh Ha'ayin, Israel) located at the Horticultural Sciences Department Protected Agriculture Project, part of the University of Florida Horticultural Research Unit in Gainesville. The sidewalls were 3.7 $\mathrm{m}(\mathrm{l} 2 \mathrm{ft})$ high with a $1-\mathrm{m}(3.3-\mathrm{ft})$ roof vent at an $8-\mathrm{m}(26.2-\mathrm{ft})$ height. Both the sidewalls and roof vents were covered with $0.6-\mathrm{mm}$ (30-mesh) screen (Klaymen Meteor Ltd., Petah-Tikva, Israel) to prevent insect movement into or out of the greenhouse. The roof was covered with double-layer polyethylene plastic (Ginegar Plastic Products Ltd., Kibbutz Ginegar, Israel). The greenhouse was cooled using passive ventilation and was heated with diesel-powered heaters (Sundair, Sunderman Mfg., Co., Baltic, S. Dak.) when temperatures dropped below $16{ }^{\circ} \mathrm{C}\left(60.8{ }^{\circ} \mathrm{F}\right)$. In 2001 , temperatures ranged from 7 to $41^{\circ} \mathrm{C}\left(44.6\right.$ to $\left.105.8^{\circ} \mathrm{F}\right)$ throughout the season. Temperatures were similar in the spring of 2002,9 to $40^{\circ} \mathrm{C}(48.2$ to $104.0^{\circ} \mathrm{F}$ ) with less than 40 nights below $15{ }^{\circ} \mathrm{C}\left(59.0^{\circ} \mathrm{F}\right)$.

Seedlings were transplanted $9 \mathrm{Feb}$. 2001 and 11 Feb. 2002 into 11.4-L (3-gal) black polyethylene nursery pots (Lerio Co., Kissimmee, Fla.). Four equidistant, $1.5-\mathrm{cm}$-diameter $(0.59$ inch) drainage holes were drilled about $5.1 \mathrm{~cm}$ ( 2 inches) from the bottom of the pot. Pots were filled with one of three media treatments: pine bark, coarse-grade perlite, or medium-grade perlite. The pine bark was screened by the manufacturer (Elixson Wood Products, Starke, Fla.) to a size less than 2.5 $x 2.5 \mathrm{~cm}$ ( 1 inch). Both the mediumand coarse-grade perlites were screened by the manufacturer (Airlite Processing Corp., Vero Beach, Fla.) to 1 to $2 \mathrm{~mm}$ (18 mesh) and 2 to $3 \mathrm{~mm}$ (10 mesh), respectively. Each plot consisted of nine plants. Single rows were $1.2 \mathrm{~m}(4 \mathrm{ft})$ apart with $30.5 \mathrm{~cm}$ (12 inches) from center to center of each pot.

To determine the effects of media type on irrigation used by the plants, the three center plants of each plot were raised to collect leachate in containers that were placed below them. Beginning one week after transplanting, leachate volumes were collected from a 24-h period two times each week during each experiment (for a total of 19 collection dates). Leachate volume was divided by total amount of irrigation delivered during the 24 -h period and converted into percent (\% leachate) for statistical analysis.

Irrigation scheduling was based on plants grown in coarse perlite. Irrigation volumes were delivered to achieve the plant need plus 10 to $20 \%$ leachate. When leachate dropped below $10 \%$ of total irrigation of plants grown in the coarse perlite treatment, irrigation to all pots was increased gradually in $200-\mathrm{mL}$ (6.8-fl oz) increments (per day) until 10\% daily leachate occurred. All plants were irrigated on the same schedule using a programmable timer (Sterling 12; Superior Controls, Valencia, Calif.).

A complete nutrient solution based on University of Florida's recommendations for greenhouse cucumber was delivered during each irrigation event (Hochmuth, 2001). Nitrogen from calcium nitrate, potassium nitrate 
and ammonium nitrate was increased from $120 \mathrm{mg} \cdot \mathrm{L}^{-1}$ at transplant to $150 \mathrm{mg} \cdot \mathrm{L}^{-1} 3$ weeks after planting. Nitrogen was increased from 150 to $180 \mathrm{mg} \cdot \mathrm{L}^{-1}$ at first harvest where it remained until the end of the season. Potassium(from potassium chloride and potassium nitrate) concentrations were increased between transplanting and first harvest from 150 to 200 $\mathrm{mg} \cdot \mathrm{L}^{-1}$ to prevent deficiencies (Shaw et al., 2000). Phosphorus (phosphoric acid), calcium (calcium nitrate), magnesium (magnesium sulfate), sulfur (sulfate containing fertilizers) and all micronutrient concentrations remained the same throughout the season at $\mathbf{5 0}$ $\mathrm{mg} \cdot \mathrm{L}^{-1}$ phosphorus, $135 \mathrm{mg} \cdot \mathrm{L}^{-1}$ calcium, $50 \mathrm{mg} \cdot \mathrm{L}^{-1}$ magnesium, $65 \mathrm{mg} \cdot \mathrm{L}^{-1}$ sulfur, $3 \mathrm{mg} \cdot \mathrm{L}^{-1}$ iron (Sequestrene 330 ; Becker Underwood Inc., Ames, Iowa), $0.2 \mathrm{mg} \cdot \mathrm{L}^{-1}$ copper (copper sulfate), $0.8 \mathrm{mg} \cdot \mathrm{L}^{-1}$ manganese (manganese sulfate), $0.3 \mathrm{mg} \cdot \mathrm{L}^{-1}$ zinc (zinc sulfate), $0.7 \mathrm{mg} \cdot \mathrm{L}^{-1}$ boron (Solubor; U.S. Borax Inc., Valencia, Calif.), and $0.06 \mathrm{mg} \cdot \mathrm{L}^{-1}$ molybdenum (sodium molybdate). The $\mathrm{pH}$ of the final solution was maintained between 5.5 and 6.5 .

Powdery mildew (Sphaerotheca fuliginea) was controlled using alternating sprays of azoxystrobin (Quadris;Zeneca Agricultural Products, Wilmington, Del.) and myclobutanil (Nova; Rohm \& Haas Co., Philadelphia, Pa.), beginning 4 weeks after transplanting. Both fungicides were sprayed twice at 2 -week intervals (Shaw et al., 2000).

Insect pests were biologicallycontrolled in both seasons using beneficial insects. When tested on the cucumber plants, the use of chemical insecticides or soap sprays resulted in leaf burning, necrosis, and stunted plant growth. Thus, alternative pest control measures that did not injure the plants were needed. Green peach aphids (Myzuspersicae) were controlled using lady beetle larvae (Hippodamia convergens, Entomos, Gainesville, Fla.) and parasitic wasps (Aphidius colemani; IPM Laboratories, Locke, N.Y.). Beginning the week of transplanting, approximately one lady beetle larva was released per plant per week. During Spring 2001, 500 Aphidius colemani were released on 30 Mar. The parasitic wasp population had naturally begun by this time. During Spring 2002, the wasp population was established before aphid levels were above control threshold by releasing Aphidius colemani for 3 consecutive weeks at a rate of 500/ week, beginning 3 weeks after planting. Two-spotted spider mites (Tetranychus urticae) were controlled by releasing predatory mites (Neoselius californicus; Biotactics Inc., Perris, Calif.) and Orius insidious (Entomos, Gainesville, Fla.). Predatory mites (quantity 3000) were released at 4 and 6 weeks after transplanting. Orius insidious were released twice during spring 2001 on 30 Mar. and $20 \mathrm{Apr}$. at a rate of one predator per plant. In Spring 2002, Orius insidious were released on a weekly basis until 26 Apr.

Cucumber harvests occurred about every other day from 12 Mar. to 3 May 2001 and 14 Mar. to 24 May 2002. There were 21 harvests in 2001 and 27 harvests in 2002. Fruit were harvested from each plot, graded by separating them based on fruit quality into fancy, No. 1, oversized, or culls, and weighed (Shaw et al., 2000). Total marketable yield was calculated as the sum of fancy, No. 1 and oversized yields.

The experimental design was a randomized-complete-block design with four replicates. Yield and leachate data from each season were analyzed using analysis of variance and means were separated using Duncan's multiple range test at $P \leq 0.05$ (SAS Institute, Cary, N.C.).

\section{Results and discussion}

For all yield variables there were no significant interactions between type of media and season, therefore, yield data was combined over seasons (Table $2)$. Type of media did not significantly affect yield or weight of any grade of fruit per plant. About 26 fancy fruit [3 kg (6.6 lb)] and 18 No. 1 fruit [2 $\mathrm{kg}(4.4 \mathrm{lb})]$ were harvested per plant regardless of media type. Cull fruit were minimal in both seasons at less than eight fruit per plant.

On 10 May 2002, Publix Supermarkets (a leading regional retail grocery store chain in Florida) sold Beit Alpha cucumber for $\$ 3.73 / \mathrm{kg}(\$ 1.69 /$ lb). This corresponds to $\$ 510,000 /$ ha (\$206,397/acre) per crop retail value [production at $5 \mathrm{~kg} /$ plant $(11.0 \mathrm{lb} /$ plant $), 3$ plants $/ \mathrm{m}^{2}\left(0.28\right.$ plant $\left.\left./ \mathrm{ft}^{2}\right)\right]$. Growers in Florida receive about $75 \%$ of the market price (personal communication, name withheld due to respect of privacy) and produce three crops annually (spring, summer, and fall/winter). Growers in Baja California, Mexico ship to markets in Los Angeles and receive up to $\$ 3.00 / \mathrm{kg}(\$ 1.36 / \mathrm{lb})$ with an average of $\$ 1.23 / \mathrm{kg}(\$ 0.56 / \mathrm{lb})$ (C. Cardenas, personal communication; A. Escalante, personal communication).

Average fruit weight was not affected by media type (Table 2). Regardless of media, average cucumber weight was $127 \mathrm{~g}(4.5 \mathrm{oz})$. Total marketable fruit weights per plant and per square meter were not affected by type of media. Averaged over media types, total marketable fruit weight per plant was $6 \mathrm{~kg}(13.2 \mathrm{lb})$ or 20 $\mathrm{kg} \cdot \mathrm{m}^{-2}\left(4.1 \mathrm{lb} / \mathrm{ft}^{2}\right)$ Previous research by Shaw et al. (2000) reported marketable yield of 'Alexander' produced during the spring season was $6.1 \mathrm{~kg}$ $(13.45 \mathrm{lb})$ per plant, therefore, yields for this study were consistent with the literature.

Total marketable fruit numbers per plant and per square meter were significantly affected by type of media. Plants grown in medium-grade perlite produced more fruit than those grown

Table 2. Total season yield per plant for each fruit grade category of Beit Alpha cucumber 'Alexander' grown in three different media in Gainesville, Fla., Spring 2001 and 2002.

\begin{tabular}{|c|c|c|c|c|c|c|c|c|c|c|c|}
\hline \multirow[b]{2}{*}{$\begin{array}{l}\text { Media } \\
\text { type }^{z}\end{array}$} & \multicolumn{11}{|c|}{ Yield variable } \\
\hline & $\begin{array}{c}\text { Avg fruit } \\
\text { wt (g) }\end{array}$ & $\begin{array}{l}\text { Mkt. } \\
\text { (no.) }\end{array}$ & $\begin{array}{c}\text { Mkt. } \\
\text { wt (kg) }\end{array}$ & $\begin{array}{c}\text { Fancy } \\
\text { (no.) }\end{array}$ & $\begin{array}{c}\text { Fancy } \\
\text { wt (kg) }\end{array}$ & $\begin{array}{r}\text { No. } 1 \\
\text { (no.) }\end{array}$ & $\begin{array}{c}\text { No. } 1 \\
\text { wt (kg) }\end{array}$ & $\begin{array}{c}\text { Oversize } \\
\text { (no.) }\end{array}$ & $\begin{array}{c}\text { Oversize } \\
\text { wt (kg) }\end{array}$ & $\begin{array}{l}\text { Culls } \\
\text { (no.) }\end{array}$ & $\begin{array}{c}\text { Culls } \\
\text { wt (kg) }\end{array}$ \\
\hline Medium perlite & 126 & $50 a$ & 6.3 & 27 & 3.2 & 18 & 2.1 & 5 & 0.9 & 8 & 0.6 \\
\hline Pine bark & 124 & $47 \mathrm{ab}$ & 5.8 & 26 & 2.9 & 16 & 2.0 & 5 & 1.0 & 7 & 0.5 \\
\hline$P$ value & 0.0542 & $0.0452^{*}$ & 0.0615 & 0.1499 & 0.1759 & 0.2670 & 0.4021 & 0.9708 & 0.9437 & 0.6147 & 0.2664 \\
\hline
\end{tabular}

${ }^{2}$ Mean separation between media types within each column using Duncan's multiple range test, ${ }^{*} P \leq 0.05$. For all yield variables, the year $\times$ media interaction was non-significant; $1 \mathrm{~g}=0.035 \mathrm{oz}, 1.0 \mathrm{~kg}=2.205 \mathrm{lb}$. 
in coarse-grade perlite, 50 versus 45 fruit/plant and 165 versus 149 fruit/ $\mathrm{m}^{2}\left(15.3\right.$ versus 13.8 fruit $\left./ \mathrm{ft}^{2}\right)$, respectively. There was no significant difference between fruit number per plant and per square meter of plants grown in medium-grade perlite compared to pine bark [average 49 fruit/plant and
160 fruit $/ \mathrm{m}^{2}$ (14.9 fruit $\left./ \mathrm{ft}^{2}\right)$ ]. Yields reported here are similar to those reported by Shaw et al. (2000). Shaw et al. (2000) reported that Beit Alpha cucumber yields per plant are more than three times greater than Dutchtype cucumbers which only average 14 fruit/plant when produced in passive-
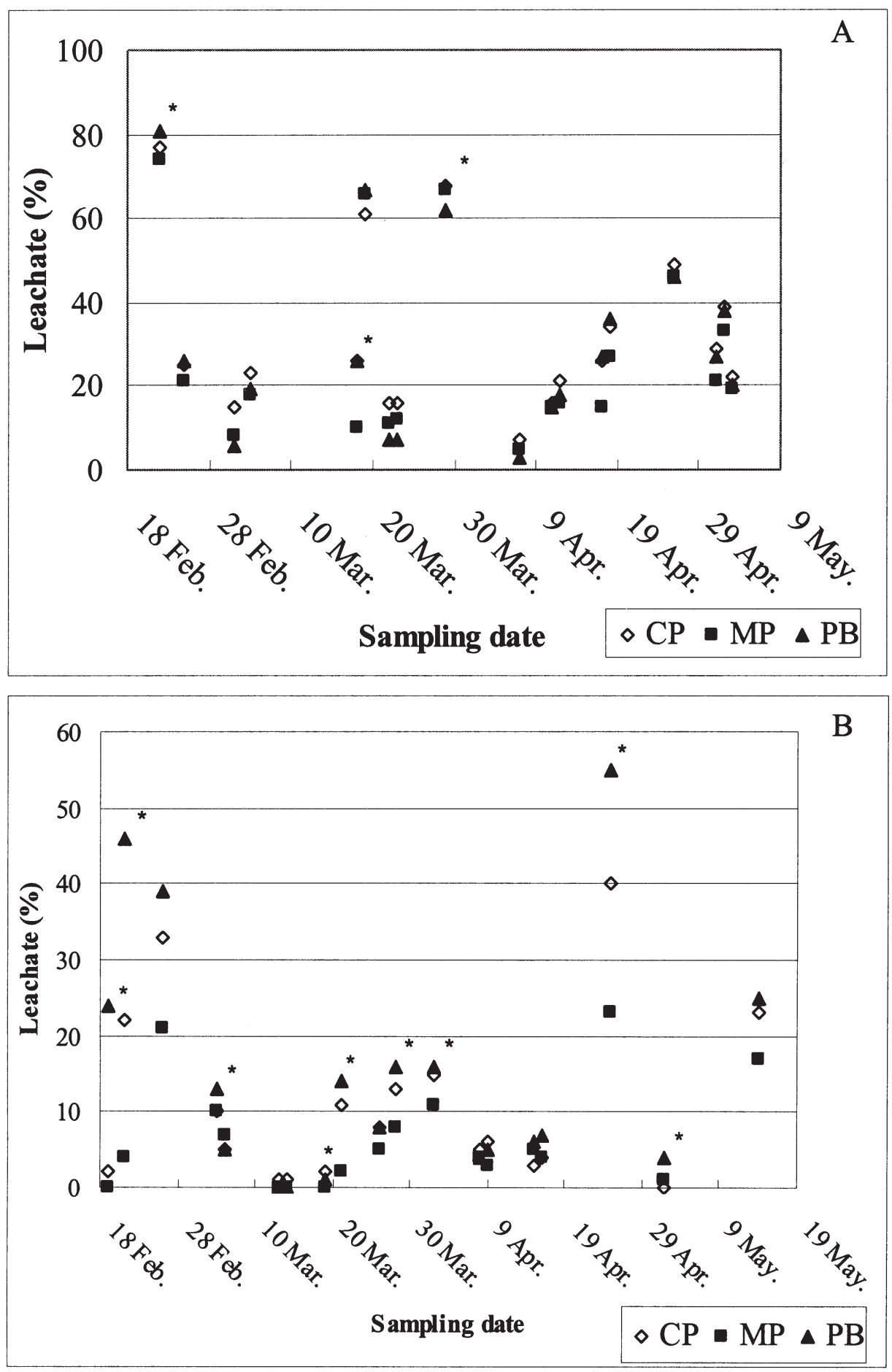

Fig. 1. Leachate values (\%) at 19 collection dates for coarse perlite $(\mathrm{CP})$, medium perlite (MP), and pine bark (PB) used as media for hydroponically produced Beit Alpha cucumber 'Alexander'; * significance at $P \leq 0.05$ level. Gainesville, Fla., Spring 2001 (A) and 2002 (B).

ventilated greenhouses in Florida.

Due to differences in amount of irrigation water applied and frequency of irrigation, leachate values (\%) were analyzed independent of season. Total volume of irrigation applied in 2001 for an 84-d crop was $118 \mathrm{~L}$ (31.2 gal) [1.4 L.d $\mathrm{d}^{-1}(0.37 \mathrm{gal} / \mathrm{d})$ per plant]. Total volume of irrigation applied in 2002 for a 103 -d crop was $208 \mathrm{~L}$ $(54.9 \mathrm{gal})\left[2.02 \mathrm{~L} \cdot \mathrm{d}^{-1}(0.53 \mathrm{gal} / \mathrm{d})\right.$ per plant]. The greater amount of irrigation applied in 2002 was due to the longer production season $(2 \mathrm{ld}$ ) under higher temperatures (maximum day temperatures were greater than 30 ${ }^{\circ} \mathrm{C}\left(86.0^{\circ} \mathrm{F}\right)$ in May 2002$)$ and more solar radiation.

In 2001, on 3 of 19 leachate collection dates, there was a significant difference between the types of media for percent leachate recovered; however, results were not consistent (Fig. 1A). On 17 Feb. 2001, more leachate occurred from pots with pine bark. On 18 Mar. 2001, leachate from pine bark and coarse-grade perlite was greater than medium-grade perlite. Lastly, on 29 Mar. 2001 , pots with pine bark had the least amount of leachate. It is important to note that the three media types responded similarly for most of the season with regards to amount of leachate recovered. Therefore, irrigation scheduling should be dependant on plant need and media type used together. However, on many collection dates in 2001, leachate values from plants grown in coarse-grade perlite were greater than $20 \%$. Since the leachate values from pots filled with coarse-grade perlite were used to determine irrigation needs of all plants, when leachates remained over $20 \%$, irrigation should have been reduced when it was not. This suggested that all plants may have been over-irrigated for most of the 2001 season and may have provided the reason why the leachate values between the media types were similar.

Leachate values recorded in 2002 varied for all media types (Fig. 1B). On 7 of 19 collection dates, more drainage occurred from pots with pine bark. Leachate values from plants grown in coarse-grade perlite were between $10 \%$ and $20 \%$. Thus, irrigation scheduling more closely followed plant demand in 2002 than in 2001 and media type was an important factor in determining irrigation scheduling. Excess leachate is recommended for greenhouse pro- 
duced vegetables, so that salts from fertilizers do not build up in the media leading to salt damage of the plant, potentially leading to a reduction in yield (Jones, 1997). However, over-irrigation is a wasteful use of both water and fertilizer.

Coarse-grade perlite was selected as the standard media for these experiments since it is the most commonly used media for greenhouse vegetable production in Florida (Tyson et al., 2001). All plants were irrigated with the same schedule based on plants grown in coarse-grade perlite. The low leachate values for plants grown in medium-grade perlite suggested that more irrigation might be required as compared to coarse-grade perlite to avoid excess salts in the media. Future experiments should be conducted where solar sensors schedule daily irrigation based on solar accumulation and individual plant/media need, thus providing efficient use of water and fertilizers.

In conclusion, marketable fruit number was greatest when plants were grown on medium-grade perlite compared to those grown on coarse-grade perlite. Marketable fruit number was not significantly different from plants grown on pine bark compared to those grown on either type of perlite. Marketable fruit weight was not affected by media. At various times during the season, more irrigation and possibly fertilizers were leached from pots containing pine bark than either grade of perlite. Pine bark has a slightly lower water holding capacity and greater air porosity than coarse-grade perlite and a different irrigation schedule should be implemented to reduce the losses that occurred when using pine bark. Pine bark is a substantially lower cost media than perlite at $\$ 8.50 / \mathrm{m}^{3}$ as compared to nearly $\$ 45 / \mathrm{m}^{3}$. The cost for pine bark is $\$ 2800 /$ ha $(\$ 1133 /$ acre $)$, and for perlite is $\$ 14,850 /$ ha ( $\$ 6010$ / acre), when using 11.4-L nursery pots at 3.3 plants $/ \mathrm{m}^{2}$. Pine bark is readily available in Florida and can be repeat- edly used and easily disposed of when fully spent. Current growers in Florida have found that pine bark can be used for up to three seasons for the production of colored bell pepper (Capsicum annum) (Gro-Tech Greenhouse Produce, Naples, Fla.). When crops are produced hydroponically, irrigation should focus on plant need in regards to the media it is grown in and the climatic conditions present. It should be explored if irrigation frequencies can be more precisely scheduled using technology such as solar sensors which measure accumulated radiation.

\section{Literature cited}

Benoit, F. and N. Ceustermans. 1995. A decade of research on ecologically sound substrates. Acta Hort. 408:17-29.

Brown, W. and G. Murphy. 2003. A profile of the Ontario greenhouse floriculture industry. Ont. Min. Agr., Food and Rural Affairs. Ont., Can. 26 Jan. 2004. <http: //www.gov.on.ca/OMAFRA/english/ crops/facts/greenflor.htm>.

Cantliffe, D.J., J. Funes, E. Jovicich, A. Paranjpe, J. Rodriguez, and N. Shaw. 2003. Media and containers for greenhouse soilless grown cucumbers, melons, peppers, and strawberries. Acta Hort. 614: 199-203.

Cantliffe, D.J., N. Shaw, E. Jovicich, J. Rodriguez, I. Secker, and Z. Karchi. 2001. Passive ventilated high-roof greenhouse production of vegetables in a humid, mild winter climate. Acta Hort. 559:195-201.

Grillas, S., M. Lucas, E. Bardopoulou, S. Sarafopoulos, and M. Voulgari. 2001. Perlite based culture systems: Current commercial applications and prospects. Acta Hort. 548:105-113.

Guler, H.G., C. Olympios, and D. Gerasopoulos. 1995. The effect of the substrate on the fruit quality of hydroponically grown melons (Cucumis melo L.). Acta Hort. 379:261-266.

Hochmuth, G. 2001. Fertilizer management for greenhouse vegetables. Florida greenhouse vegetable production hand- book. vol 3. Univ. of Fla. Coop. Ext. Serv. SP48:HS787. 26 Jan. 2004. <http: //edis.ifas.uFl.edu/CV265>.

Ingram, D., R. Henley, and T. Yeager. 1993. Growth media for container grown ornamental plants. Univ. Fla. Coop. Ext. Serv. Inst. Food Agr. Sci. Bul. 241.

Jensen, M. 2001. Controlled environment agriculture in deserts, tropics, and temperate regions-A world review. In: Intl. Symp. Design and Env. Control of Tropical and Subtrop. Greenhouses. Taichung, Taiwan, R.O.C. 15-18 Apr. 2001.

Jones, Jr., J.B. 1997. Hydroponics: A practical guide for the soilless grower. 2 nd ed. St. Lucie Press, Boca Raton, Fla.

Kaveri Agri-Care. 2004. Processed coir pith (coco-peat) for export. Kaveri Agri-Care Pvt, Ltd., Bangalore, India. 26 Jan. 2004. <http://www.tifac.org.in/do/hgt/case/ coir_pith.htm>.

Millenniumsoils Coir. 2004. Naturally the best composted coconut coir growing medium. Millenniumsoils Coir-Div. of Vgrove, Inc., St. Catherines, Ont., Can. 26 Jan. 2004. <http://vgrove.com/ home.htm $>$.

Moutere River Co. 2004. Pine bark, orchid bark, and garden bark. Moutere River Co. Ltd., Nelson, N.Z. 26 Jan. 2004. <http: //www.moutere.com/bark>.

Prasad, M. 1997. Physical, chemical, and biological properties of coir dust. Acta Hort. 450:21-27.

Shaw, N., D. Cantliffe, J. Rodriguez, S. Taylor, and D. Spencer. 2000. Beit Alpha cucumber-An exciting new greenhouse crop. Proc. Fla. State Hort. Soc. 113: 247-253.

Tyson, R.V., R.C. Hochmuth, E.M. Lamb, G.J. Hochmuth, and M.S. Sweat. 2001. A decade of change in Florida's greenhouse vegetable industry: 1991-2001. Proc. Fla. State Hort. Soc. 114:280-283.

University of Florida. 2004. University of Florida Horticultural Sciences Department Protected Agriculture Greenhouse and the Florida/Israeli Protected Agriculture Project. 26 Jan. 2004. <http: //www.hos.ufl.edu/protectedag/>. 